\title{
Oral Food Challenge
}

\author{
Mauro Calvani ${ }^{1}$, Annamaria Bianchi ${ }^{1}$, Chiara Reginelli ${ }^{2}$, Martina Peresso ${ }^{2, *}$ and Alessia Testa ${ }^{2}$ \\ 1 Operative Unit of Paediatrics, S. Camillo-Forlanini Hospital, Circonvallazione Gianicolense 87, 00152 Rome, \\ Italy; mi5660@mclink.it (M.C.); annamaria.bianchi9@yahoo.it (A.B.) \\ 2 Department of Paediatrics, Sapienza University of Rome, Viale Del Policlinico 155, 00161 Roma, Italy; \\ reginellichiara@gmail.com (C.R.); alessiatesta92@live.it (A.T.) \\ * Correspondence: peressovm@libero.it
}

Received: 19 June 2019; Accepted: 20 September 2019; Published: 27 September 2019

Abstract: Oral food challenge (OFC) is the gold standard for diagnosis of IgE-mediated and non-IgE mediated food allergy. It is usually conducted to make diagnosis, to monitor for resolution of a food allergy, or to identify the threshold of responsiveness. Clinical history and lab tests have poor diagnostic accuracy and they are not sufficient to make a strict diagnosis of food allergy. Higher concentrations of food-specific IgE or larger allergy prick skin test wheal sizes correlate with an increased likelihood of a reaction upon ingestion. Several cut-off values, to make a diagnosis of some food allergies (e.g., milk, egg, peanut, etc.) without performing an OFC, have been suggested, but their use is still debated. The oral food challenge should be carried out by experienced physicians in a proper environment equipped for emergency, in order to carefully assess symptoms and signs and correctly manage any possible allergic reaction. This review does not intend to analyse comprehensively all the issues related to the diagnosis of food allergies, but to summarize some practical information on the OFC procedure, as reported in a recent issue by The Expert Review of Food Allergy Committee of Italian Society of Pediatric Allergy and Immunology (SIAIP).

Keywords: oral food challenge; food allergy; food allergens; single-blind; placebo-controlled oral food challenge; double-blind; placebo-controlled oral food challenge

\section{Introduction}

Food allergies have been increasing: A recent systematic review and meta-analysis report that lifetime self-reported prevalence of allergy to common foods in Europe ranged from 0.1 to $6.0 \%$ [1]. Diagnosis of a food allergy is not simple, and self-reported rates of food allergies are much higher than the true prevalence [2]. Clinical history and lab tests have poor diagnostic accuracy and they cannot make a certain diagnosis of a food allergy. Thus, the oral food challenge (OFC) is the gold standard for diagnosis of a food allergy [3]. This review does not intend to analyze comprehensively all the issues related to the diagnosis of food allergy, but to summarize some practical information on the OFC procedure, as reported in a recent issue by The Expert Review of Food Allergy Committee of Italian Society of Pediatric Allergy and Immunology (SIAIP) [4].

OFC comprises the oral administration of the suspected allergen in a controlled and standardized setting. It is a complex test, which requires large healthcare (physician, nurse, hospital facilities) and family (stress, fear) resources. OFC is useful to confirm or exclude the diagnosis of a food allergy (both for IgE-mediated and non-IgE mediated reactions), to assess the tolerability of a food in a child with a previous food allergy, or to identify the threshold of responsiveness [5]. Other indications for the oral food challenge are to test a particular food in sensitized patients who have never ingested that food or to test a cross-reactive food never introduced in the diet [5-7].

Children with a history of recent anaphylaxis (within 12 months) and detectable levels of IgE specific to a suspected food should be excluded from being tested with the oral food challenge [5]. 
Patients should also not be challenged if affected by atopic disease that might interfere with the assessment, diseases that might affect safety, or if they are taking drugs that might interfere with the assessment or affect safety [8].

\section{Clinical History}

An accurate collection of clinical history is essential to define when further diagnostic investigations are needed and how to implement them and interpret their results. Clinical history aims to identify food allergy cases by investigating symptoms, possible allergens, relationships between food ingestion and onset of symptoms, ingested dose, intercurrent diseases, potential cofactors or cross-reactivity, other allergies, the role of the suspected allergen in the diet, and possible effects of previous diets [9]. The goal of clinical history is also to identify the possible immunological mechanism underlying the food allergy. Some conditions may point to IgE-mediated allergic reactions such as signs of skin involvement (urticaria, angioedema, erythematous rash), respiratory features (rhino conjunctivitis, cough, dyspnea, or asthma) or gastrointestinal ones (oral itching, nausea, vomit, abdominal pain, and diarrhea), or even malaise and hypotension that occur within $2 \mathrm{~h}$ after ingestion of a probable allergen. Food Dependent Exercise Induced Anaphylaxis (FDEIA) is an exception as it arises after a greater temporal latency. The longest intervals between eating and onset of the symptoms were $3.5 \mathrm{~h}$, while between the start of exercise and the onset of symptoms it was $50 \mathrm{~min}$ [10] Subjects affected by FDEIA are sensitized to the food responsible for anaphylaxis, even if specific IgE blood levels are lower than in other food allergies. Ingestion of the suspected food provokes clinical manifestations only when followed by physical exercise. At the same time, physical activity does not induce adverse reactions if not preceded by food ingestion. In allergen-specific FDEIA, the role of exercise (or other co-factors such as aspirin, alcohol, etc.) is crucial, because it prompts the development of clinical reactions to a food that is commonly eaten by the patient, without any clinical manifestation [11].

Delayed symptoms, however, especially those affecting the gastrointestinal tract, lead towards a non-IgE-mediated reaction or to a mixed IgE- and non-IgE-mediated reaction (Table 1).

Table 1. Clinical symptoms of food allergy.

\begin{tabular}{|c|c|c|c|c|c|c|c|c|}
\hline & Cutaneous & Ocular & $\begin{array}{c}\text { Upper } \\
\text { Respiratory }\end{array}$ & $\begin{array}{c}\text { Lower } \\
\text { Respiratory }\end{array}$ & Gastrointestinal & Cardiovascular & $\begin{array}{l}\text { Central } \\
\text { Nervous } \\
\text { System }\end{array}$ & Others \\
\hline \multicolumn{9}{|c|}{ IgE-Mediated Food Allergy } \\
\hline & $\begin{array}{c}\text { Flushing, } \\
\text { pruritus } \\
\text { urticaria, } \\
\text { angioedema }\end{array}$ & $\begin{array}{c}\text { Pruritus, } \\
\text { conjunctival } \\
\text { erythema, } \\
\text { lacrimation, } \\
\text { periorbital } \\
\text { edema }\end{array}$ & $\begin{array}{l}\text { Sneezing, } \\
\text { rhinorrhea, } \\
\text { congestion, } \\
\text { hoarseness, } \\
\text { cornage, } \\
\text { tirage }\end{array}$ & $\begin{array}{l}\text { Shortness of } \\
\text { breath, } \\
\text { wheeze, } \\
\text { intercostal } \\
\text { retractions, } \\
\text { cough }\end{array}$ & $\begin{array}{c}\text { Nausea, } \\
\text { vomiting, } \\
\text { diarrhea, pain, } \\
\text { oral angioedema }\end{array}$ & $\begin{array}{l}\text { Tachycardia, } \\
\text { bradycardia, } \\
\text { vertigo, } \\
\text { hypotension, } \\
\text { syncope }\end{array}$ & $\begin{array}{l}\text { Hypo-reactivity, } \\
\text { weeping, } \\
\text { irritability, } \\
\text { anxiety, } \\
\text { drowsiness, } \\
\text { loss of } \\
\text { consciousness }\end{array}$ & $\begin{array}{c}\text { Sense of } \\
\text { impending } \\
\text { doom } \\
\text { Uterine } \\
\text { contractions }\end{array}$ \\
\hline \multicolumn{9}{|c|}{ Non-IgE-Mediated Food Allergy } \\
\hline $\mathrm{AD}^{*}$ & Rash eczema & & & & & & & \\
\hline FPIES * & Pallor & & & & $\begin{array}{c}\text { Severe vomiting, } \\
\text { diarrhea }\end{array}$ & $\begin{array}{l}\text { Hypotension, } \\
\text { shock }\end{array}$ & Lethargy & Hypothermia \\
\hline $\mathrm{EoE}^{*}$ & & & & & $\begin{array}{c}\text { Nausea, } \\
\text { vomiting, } \\
\text { retrosternal pain } \\
\text { and/or burning, } \\
\text { dysphagia, } \\
\text { esophageal food } \\
\text { impaction }\end{array}$ & & & Poor growth \\
\hline
\end{tabular}

* AD, atopic dermatitis; FPIES, food protein-induced enterocolitis syndrome; FPIAP, food protein-induced proctocolitis; EoE, eosinophilic esophagitis. 


\section{Diagnostic Tests}

The diagnosis of IgE-mediated food allergy relies on a compatible clinical history and on both the results of skin prick tests (SPTs) and the determination of serum-specific immunoglobulins E (sIgEs). Both tests have good sensitivity but low specificity, which means that they are often positive in non-allergic subjects [12]. It is well known that the greater the SPT wheal size or the sIgEs level, the greater the probability of showing allergic symptoms [13]. Thus, many authors have tried to determine a cut-off for wheal sizes or for sIgEs levels able to predict a positive challenge. Several systematic reviews $[14,15]$, guidelines, and international consensus $[5,8,16]$ have suggested the use of cut-off values to reach a diagnosis of some food allergies (e.g., milk, egg, peanut, etc.) without performing an OFC. However, the proposed cut-offs vary depending on various factors, such as type of food, clinical picture, the population enrolled in the study, age [17], cooking of food [18], the type of allergen used to perform SPTs (e.g., commercial extract, raw egg, or heated egg) [19] etc., and sometimes also taking into account these factors. The Food Allergy Committee of Italian Society of Pediatric Allergy and Immunology (SIAIP) recently published two systematic reviews on the predictive value of SPTs and specific IgEs for egg [14] and milk [20].

As for egg allergy, a total of 37 articles were included, and their methodological quality was evaluated according to the criteria given by the QUADAS-2 tool [21]. Despite the division into groups based on the degree of cooking, age, and the type of allergen used to perform the SPTs, proposed cut-offs, with the exception of cut-offs for raw egg, showed a large variability, especially for sIgEs.

The second systematic review on the predictive value of SPTs and specific IgEs for milk allergy included 31 papers and grouped them according to patients' age, allergen type, and cooking degree of the milk used for the oral food challenge. Grouping studies has reduced the variability of the cut-offs proposed, but not substantially. However, in children $<2$ years, proposed cut-offs seem to be homogeneous enough. The studies with the highest methodological quality suggest a $95 \%$ positive predictive value (PPV) cut-off for sIgEs of $5 \mathrm{KUA} / \mathrm{L}$ [22] and a $98 \%$ specificity cut-off for prick-by-prick $(\mathrm{PbP})$ with fresh milk of $8 \mathrm{~mm}$ [23].

The two systematic reviews concluded that, both for egg and milk allergies, no proposed cut-off can be used to definitely confirm a diagnosis of Cow's Milk Allergy (CMA) or egg allergy. However, with these limits, above all in children $<2$ years, when sIgE against CM or egg, or when SPTs are above the cut-off indicated in Tables 2 and 3, the real need for a diagnostic confirmation of CMA or egg allergy through an OFC should be carefully evaluated.

As regards peanut and nut allergies, a recent guideline for the diagnosis of peanut and tree nut allergies stated that an SPT of $\geq 8 \mathrm{~mm}$ or an $\operatorname{sIgE} \geq 15 \mathrm{KU} / \mathrm{L}$ to peanut is highly predictive of clinical allergy. Cut-off values are not available for tree nuts. However, it is generally accepted that a cut-off $\mathrm{SPT} \geq 8 \mathrm{~mm}$ for a specific tree nut is highly suggestive of clinical allergy [24].

Table 2. Cutoffs proposed for milk allergy by the methodologically best studies. From: Bianchi A et al., [15] and Cuomo B et al., modified [20].

\begin{tabular}{|c|c|c|c|c|}
\hline & $<2$ years & Ref. & $>2$ years & Ref. \\
\hline \multicolumn{5}{|c|}{ Fresh Cow's Milk (Skin Prick Test) } \\
\hline $\begin{array}{c}\text { Cow's milk } \\
\text { (commercial extract) }\end{array}$ & $\begin{array}{c}6 \mathrm{~mm} \\
(100 \% \mathrm{Sp}) \\
(\mathrm{LR} 13.2)\end{array}$ & Sporik, [25] & $\begin{array}{c}8 \mathrm{~mm} \\
(100 \% \mathrm{Sp}) \\
\text { (LR infinite) }\end{array}$ & Sporik, [25] \\
\hline $\begin{array}{c}\text { Fresh cow's milk } \\
\text { prick-by-prick (PbP) }\end{array}$ & $\begin{array}{c}8 \mathrm{~mm} \\
(98 \% \mathrm{Sp}) \\
(\mathrm{LR} 9.5)\end{array}$ & Saarinen, [23] & $\begin{array}{c}9 \mathrm{~mm} \\
(95 \% \mathrm{PPV})\end{array}$ & Onesimo, [26] \\
\hline $\begin{array}{c}\alpha \text { - Lactalbumin } \\
\text { (commercial extract) }\end{array}$ & - & - & $\begin{array}{c}4.9 \mathrm{~mm} \\
(95 \% \mathrm{PPV})\end{array}$ & Onesimo, [26] \\
\hline $\begin{array}{c}\beta \text {-Lactoglobulin } \\
\text { (commercial extract) }\end{array}$ & - & - & $\begin{array}{c}5.6 \mathrm{~mm} \\
(95 \% \mathrm{PPV})\end{array}$ & Onesimo, [26] \\
\hline $\begin{array}{c}\text { Casein } \\
\text { (commercial extract) }\end{array}$ & - & - & $\begin{array}{c}4.3 \mathrm{~mm} \\
(95 \% \mathrm{PPV})\end{array}$ & Onesimo, [26] \\
\hline
\end{tabular}


Table 2. Cont.

\begin{tabular}{|c|c|c|c|c|}
\hline & $<2$ years & Ref. & $>2$ years & Ref. \\
\hline \multicolumn{5}{|c|}{ Baked Cow's Milk (Skin Prick Test) } \\
\hline $\begin{array}{c}\text { Cow's milk } \\
\text { (commercial extract) }\end{array}$ & - & - & $\begin{array}{l}15 \mathrm{~mm} \\
(67 \% \mathrm{Sp}) \\
\text { (LR 3.5) }\end{array}$ & Nowak-Wegrzyn, [27] \\
\hline \multicolumn{5}{|c|}{ Fresh Cow's Milk (IgEs) } \\
\hline Cow's milk & $\begin{array}{c}5 \mathrm{kU}_{\mathrm{A}} / \mathrm{L} \\
(95 \% \mathrm{PPV}) \\
(\mathrm{LR} 30) \\
3.5 \mathrm{kU}_{\mathrm{A}} / \mathrm{L} \\
(98 \mathrm{Sp}) \\
(\mathrm{LR} 12.5) \\
4.18 \mathrm{kU} \mathrm{U}_{\mathrm{a}} / \mathrm{L} \\
(100 \% \mathrm{PPV}) \\
\text { (LR infinite) }\end{array}$ & $\begin{array}{l}\text { Garcia-Ara, [22] } \\
\text { Saarinen, [23] } \\
\text { Keslin, [28] }\end{array}$ & - & - \\
\hline
\end{tabular}

PPV, positive predictive value; $\mathrm{Sp}$, specificity; LR, likelihood ratio; PbP, prick-by-prick.

Table 3. Cut-offs proposed for egg allergy by the methodologically best studies. From: Calvani M et al., [14].

\begin{tabular}{|c|c|c|c|c|}
\hline & $<2$ years & Ref. & $>2$ years & Ref. \\
\hline \multicolumn{5}{|c|}{ Raw Egg (Skin Prick Test) } \\
\hline $\begin{array}{c}\text { Raw egg } \\
\text { (commercial extract) }\end{array}$ & $\begin{array}{c}\mathrm{SPT}=4 \mathrm{~mm} \text { wheal } \\
(95 \% \text { PPV) } \\
\text { (LR 6.7) }\end{array}$ & Peters, [29] & $\begin{array}{c}\mathrm{SPT}=10 \mathrm{~mm} \text { wheal } \\
(95 \% \mathrm{Sp}) \\
(\text { LR 5.2) }\end{array}$ & Vazquez-Ortiz, [30] \\
\hline Raw egg $(\mathrm{PbP})$ & - & - & $\begin{array}{c}\mathrm{PbP}=14 \mathrm{~mm} \text { wheal } \\
(95 \% \text { PPV) } \\
\text { n.d. }\end{array}$ & Mehl, [31] \\
\hline $\begin{array}{c}\text { Ovoalbumin } \\
\text { (commercial extract) }\end{array}$ & - & - & $\begin{array}{c}\mathrm{SPT}=10 \mathrm{~mm} \text { wheal } \\
(95 \% \mathrm{Sp}) \\
(\mathrm{LR} \mathrm{5.2)})\end{array}$ & Vazquez-Ortiz, [30] \\
\hline $\begin{array}{c}\text { Ovomucoid } \\
\text { (commercial extract) }\end{array}$ & - & - & $\begin{array}{l}\mathrm{SPT}=8.5 \mathrm{~mm} \\
(95 \% \mathrm{Sp}) \\
(\mathrm{LR} 7.1)\end{array}$ & Vazquez-Ortiz, [30] \\
\hline \multicolumn{5}{|c|}{ Heated Egg (Skin Prick Test) } \\
\hline $\begin{array}{c}\text { Raw egg } \\
\text { (commercial extract) }\end{array}$ & $\begin{array}{c}\mathrm{SPT}=5 \mathrm{~mm} \text { wheal } \\
(100 \% \text { Spec }) \\
\text { (LR 7.3) }\end{array}$ & Sporik, [25] & $\begin{array}{c}\text { SPT = } 11 \text { mm wheal } \\
(95 \% \text { Sp) } \\
(\text { LR 2.3) }\end{array}$ & Vazquez-Ortiz, [30] \\
\hline $\begin{array}{c}\text { Ovoalbumin } \\
\text { (commercial extract) }\end{array}$ & - & - & $\begin{aligned} \mathrm{SPT}= & 10.5 \mathrm{~mm} \text { wheal } \\
& (95 \% \mathrm{Sp}) \\
& (\mathrm{LR} 4.7)\end{aligned}$ & Vazquez-Ortiz, [30] \\
\hline $\begin{array}{c}\text { Ovomucoid } \\
\text { (commercial extract) }\end{array}$ & - & - & $\begin{array}{c}\mathrm{SPT}=13 \mathrm{~mm} \text { wheal } \\
(95 \% \mathrm{Sp}) \\
(\text { LR } 2)\end{array}$ & Vazquez-Ortiz, [30] \\
\hline \multicolumn{5}{|c|}{ Raw Egg (sIgE) } \\
\hline Raw egg & $\begin{array}{c}\mathrm{sIgE}=1.7 \mathrm{kUA} / \mathrm{L} \\
(95 \% \text { PPV) } \\
(\mathrm{LR} 21.2)\end{array}$ & Peters, [29] & $\begin{array}{c}\mathrm{sIgE}=3.6 \mathrm{kUA} / \mathrm{L} \\
(95 \% \mathrm{PPV}) \\
(\mathrm{LR} 11) \\
\text { sIgE }=6 \mathrm{kUA} / \mathrm{L} \\
(95 \% \text { PPV) } \\
(\mathrm{LR} 6.4) \\
\mathrm{sIgE}=7.3 \mathrm{kUA} / \mathrm{L} \\
(95 \% \text { PPV) } \\
(\mathrm{LR} 11.4)\end{array}$ & $\begin{array}{c}\text { Vazquez-Ortiz, [30] } \\
\text { Sampson, [32] } \\
\text { Ando, [33] }\end{array}$ \\
\hline
\end{tabular}




\section{Novel Diagnostic Approach}

Allergen component-resolved diagnostic testing (CRD), first proposed by Valenta about 20 years ago [34], is a method able to dose purified or recombinant allergens for the identification of specific molecules causing sensitization or clinical allergy. CRD can be performed either in single test formats or in a microarray, testing a range of over 100 purified allergens simultaneously. It has been demonstrated that CRD may increase allergy diagnosis accuracy, both in respiratory and in food allergy.

A recent EAACI Molecular Allergology User's guide proposed that Molecular Diagnostics (MD) can improve total allergen IgE testing including where: (1) There are low abundant and/or labile food proteins in conventional allergy tests, (2) MD provides information on risk or severity-associated molecules, and (3) MD provides indicators of food-related cross-reactivity or (4) markers of genuine (species-specific) sensitization. Among the other main indicators of CRD, there are idiopathic anaphylaxis, delayed red meat anaphylaxis, wheat-dependent exercise-induced anaphylaxis, differentiated between highversus low-risk molecules from foods giving rise to food-induced anaphylaxis (peanut, nuts, shrimp, etc.), baked egg or milk allergy (ovomucoid, casein), etc. [14,20,35-37].

On the contrary, it is of little use when there is a convincing history of IgE-mediated allergy and a positive SPT or SIgE to the relevant whole food allergen; this information is already sufficient to make a diagnosis [38].

Basophil activation tests (BATs) have been applied in the diagnosis of cow's milk [39], egg [40], and peanut [41] allergies, showing higher specificity and more negative predictive value than SPTs and SIgEs, without losing sensitivity or positive predictive value. However, BATs are available only in a few laboratories, thus it is still limited for research purposes on food allergy [9].

\section{How Can We Use Cut-Offs in Clinical Practice?}

Two different kinds of cut-off values were proposed in the literature, both for SPTs and for sIgEs: Those based on a high positive predictive value (95\% PPV) and those based on a high specificity (95\% specificity). The first ones, being based on the predictive value, depend on the prevalence of an allergy in the studied population and are applicable in allergy centers where it is assumed that the prevalence of food allergy is similar to the one found in the studies providing the values [42]. On the contrary, the cut-off values based on $95 \%$ specificity do not change with the prevalence of the disease in the population and give us the chance to better select the children to test with OFC, given the high risk of a positive challenge. The positive predictive value (PPV) is the probability that a patient has a food allergy if the test is positive. However, these predictive values are dependent on the population prevalence and other variables (the food allergen in question, background history, age, sex, geographic location, ethnicity, and concomitant allergies). It is therefore not possible to easily apply predictive values across different populations and in different settings [9].

Apart from these specific cases, it has been suggested to use the likelihood ratio (LR), which does not depend upon the prevalence of the illness and offers a different diagnostic approach, applicable on single patients independently. The LR is realized by combining (1) the pre-test probability, which can be inferred from the clinical record of the patient with (2) the post-test probability, namely the diagnostic test result (e.g., SPT or Specific IgE for suspected food). The LR highlights the number of times that a given result can be more likely seen in a patient allergic to a specific food compared to a patient who tolerates that food. The higher the LR, the higher the probability of an allergy. If the LR $>10$, it makes the OFC useless. [9,43]. The LR can be obtained with a simple mathematic formula (sensibility/l-specificity) or by using Fagan nomogram, which simplifies the calculation to a percentage instead of an odd ratio.

Establishing the pre-test probability with precision is not always easy, but it can be determined with a certain approximation, knowing the medical history of the child. The more typical the medical history, the more probable it is that the clinical situation reported has been caused by a food allergy. 


\section{When Can We Decide on Elimination Diet Without OFC?}

In 2009, the French position paper on food allergy [16] stated that "OFC is not indicated in children with a clinical history suggestive of allergy and positive results in skin tests or specific IgE". They defined a suggestive clinical history if cutaneous signs (eczema, rash, urticaria, angioedema), gastrointestinal signs (nausea, vomiting, diarrhea, abdominal pain), respiratory signs (rhino conjunctivitis, cough, respiratory distress, bronchospasm), and/or arterial hypotension occur shortly after ingesting the food (and positive IgE test results). Recently, Food Allergy Practice Parameter [3] suggests that "OFC is not prudent or necessary to make the diagnosis of IgE- mediated food allergy if the patient has an unequivocal and convincing history of clinical reactivity to a known food allergen and positive sIgE test results (SPT or sIgE measurement)". However, in this document, a definition of an unequivocal and convincing history is lacking. In the past, Sampson defined convincing history as an immediate allergic reaction to a food within the previous 2 years that developed after an isolated ingestion of the suspected food and required emergency management by a physician. Whereas, a suggestive history consists of an immediate allergic reaction that occurred after the ingestion of a food (not necessarily in isolation) on one or more occasions but did not require emergency management by a physician or a convincing reaction that occurred more than 2 years before [32].

As no study has demonstrated the diagnostic efficacy of these or other definitions, the Expert Review of Food Allergy Committee of Italian Society of Pediatric Allergy and Immunology (SIAIP) [4] suggests a more conservative definition of convincing and suggestive histories of IgE-mediated food allergy (Box 1) and suggests that a diagnostic OFC can be deferred, due to the high probability of a reaction, where the patient presents:

- A convincing history in the presence of a specific SPT or IgE positive to the suspected food.

- A suggestive history in the presence of a specific SPT or IgE above the level of the suggested cut-off.

In all cases, the values of the wheal of the SPT, or the value of the specific IgE, do not constitute an absolute side effect to the OFC, nor to the initial diagnosis or to evaluate the development of tolerance later on.

In conclusion, specific test results can be linked with a specific probability of allergy. However, this probability is influenced by the clinical history, which determines the prevalence of an allergy in the specific patient that is being tested. It is therefore essential that the results of the investigations are interpreted in the context of the clinical history.

A simpler approach to integrate the clinical history and $\operatorname{sIgE}$ result using a table was recently proposed [44]. Starting from this approach, we have created a table which shows how it is possible, in broad terms in clinical practice, to evaluate the usefulness of an OFC, keeping in consideration both the clinical history and the results of the allergy blood or skin tests and the cut-offs. (Table 4).

Table 4. Example: A 10-month child with a suspected allergic reaction after the ingestion of egg (heated). Modified from Stiefel and Roberts.

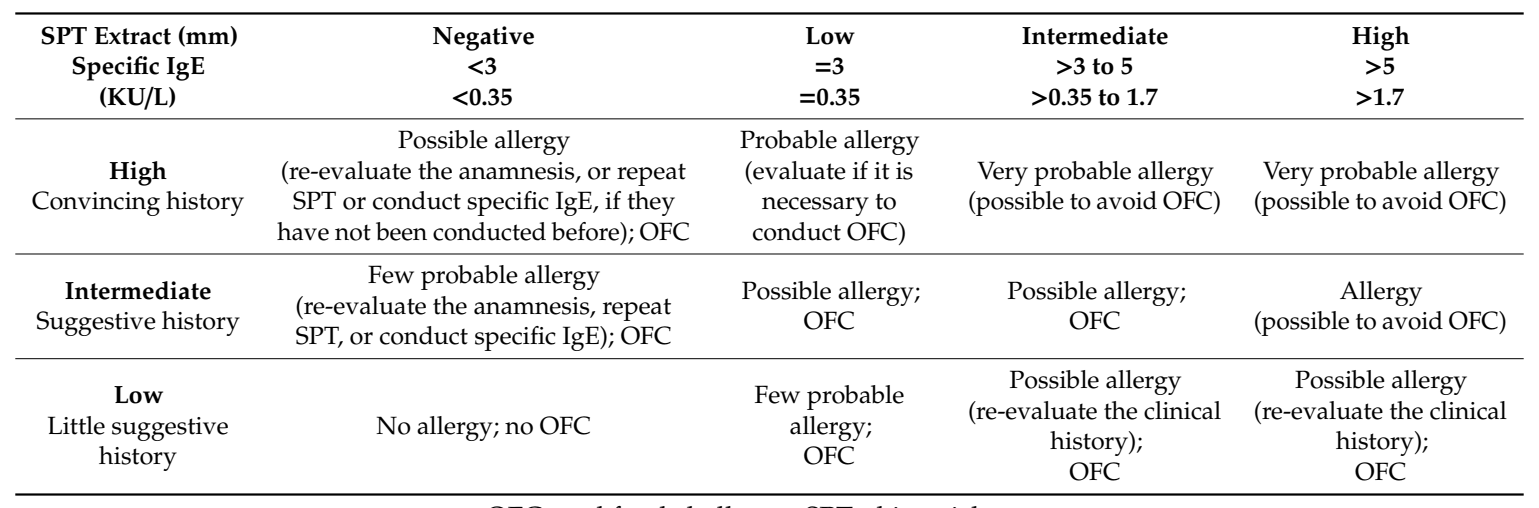

OFC, oral food challenge; SPT, skin prick test. 


\section{OFC Procedures and Schedules}

The OFC must be done when the patient has not eaten for at least $4 \mathrm{~h}$ (to anticipate immediate reactions) or for at least $12 \mathrm{~h}$ (in the case of non-immediate reactions).

Before the OFC, it is strongly recommended to [6,45]:

1. Collect medical history, which can highlight the type and severity of the previous reactions, the diet followed, and potential interruptions.

2. Collect the parents' consent form and, age permitting, also of the patients; moreover, it is necessary to inform about the risks, benefits, outcomes, and potential limits of a positive and negative OFC

3. Investigate the possible interference of pharmaceutical drugs which can hide an allergic reaction (antihistamine type H1), make it more severe (antacids, antihistamines type H2, and proton-pump inhibitors), or interfere with the administration of pharmaceutical drugs necessary to treat a potential allergic reaction (beta-blockers).

4. Have a thorough objective investigation, to ensure the child is de facto able to be receive the OFC and to obtain a comparative evaluation, pre- and post-challenge. Patients should not be challenged near treatment with systemic steroids (e.g., within 7-14 days) because disease rebound might confound the interpretation of the food challenge result.

a) In IgE-Mediated Food Allergy

The oral food challenge (OFC) may be performed as an open, single-blind, or double-blind challenge [5]. In the open OFC, both the doctor and the patient (and the family members) are aware of the food being offered. It is the simplest OFC, the least expensive in terms of time and costs, and therefore the most frequently used. On the other hand, it has the disadvantage of being at risk of failing the challenge due to the psychogenic interference in the genesis of symptoms. For this reason, its reliability is greater in the first years of life and it is variable according to child's personality and reported symptoms.

Although a negative open OFC excludes a reaction to the food, a positive result with subjective symptoms, such as itching of the mouth area, sickness, or abdominal pain, is not conclusive for a firm diagnosis of a food allergy and should be confirmed by a blind OFC [5]. In the single-blind OFC, only the doctor knows the composition of the food that is being administered. This eliminates the patient's psychogenic interference in the genesis of symptoms, but not the possible bias in the doctor's interpretation of symptoms. In the double-blind placebo test (DBPCFC), neither the doctor nor the patient are aware of when the suspected food or placebo is being administered. This minimizes the doctor's interpretation bias and the patient's psychogenic interference. For this reason, the DBPCFC is considered the gold standard for the diagnosis of food allergies; however, due to its difficult implementation, it is only used for research purposes, for clinical purposes when an open or single-blind challenge result is ambiguous, or in selected cases where any psychogenic interference in the genesis of symptoms must be excluded.

In conclusion, in the majority of cases in the first years of life or when there is a low risk of bias, connected/due to psychogenic factors, it can be performed openly. In all the other cases, it is preferable to perform a blind or double-blind placebo-controlled food challenge.

Different schemes in terms of dosage, time of administration, and dose increase can be applied to perform an OFC in an IgE-mediated food allergy. One of the most used schedules is proposed by Practall [8]. It consists of seven growing doses of food with semi-logarithmic increase of protein: 3-10-30-100-300-1000-3000 mg. Table 5 shows the amount of proteins for different kinds of food (expressed as $\mathrm{mg}$ or $\mathrm{ml}$ ). The starting dose should always be lower than the one which triggered the allergic reaction. It might be possible to adapt the starting dose to the one which was tolerated during the previous food challenge if the clinical history suggests a partial tolerance to the food in the patient. 
Table 5. Suggested dosage for principal foods, based on their protein content.

\begin{tabular}{|c|c|c|c|c|c|c|c|c|}
\hline & Dose 1 & Dose 2 & Dose 3 & Dose 4 & Dose 5 & Dose 6 & Dose 7 & Total Dose \\
\hline Protein content of food & $3 \mathrm{mg}$ & $10 \mathrm{mg}$ & $30 \mathrm{mg}$ & $100 \mathrm{mg}$ & $300 \mathrm{mg}$ & $1 \mathrm{~g}$ & $3 \mathrm{~g}$ & $4.4 \mathrm{~g}$ \\
\hline Pasteurised cow's milk* & $0.1 \mathrm{~mL}$ & $0.3 \mathrm{~mL}$ & $0.9 \mathrm{~mL}$ & $3 \mathrm{~mL}$ & $9.1 \mathrm{~mL}$ & $30.3 \mathrm{~mL}$ & $90.9 \mathrm{~mL}$ & $134.6 \mathrm{~mL}$ \\
\hline Hen's egg emulsified ^ $^{\wedge}$ & $\begin{array}{c}24.19 \mathrm{mg} \\
(0.02 \mathrm{~g})\end{array}$ & $\begin{array}{c}80.64 \mathrm{mg} \\
(0.08 \mathrm{~g})\end{array}$ & $\begin{array}{c}241.9 \mathrm{mg} \\
(0.24 \mathrm{~g})\end{array}$ & $\begin{array}{c}806.4 \mathrm{mg} \\
(0.8 \mathrm{~g})\end{array}$ & $\begin{array}{c}2419.2 \mathrm{mg} \\
(2.4 \mathrm{~g})\end{array}$ & $\begin{array}{l}8064.5 \mathrm{mg} \\
(8 \mathrm{~g})\end{array}$ & $\begin{array}{c}24,193.5 \mathrm{mg} \\
(24.1 \mathrm{~g})\end{array}$ & $35.6 \mathrm{~g}$ \\
\hline Semolina pasta dry \# & $\begin{array}{c}27.52 \mathrm{mg} \\
(0.02 \mathrm{~g})\end{array}$ & $\begin{array}{c}91.74 \mathrm{mg} \\
(0.09 \mathrm{~g})\end{array}$ & $\begin{array}{c}275.2 \mathrm{mg} \\
(0.27 \mathrm{~g})\end{array}$ & $\begin{array}{c}917.4 \mathrm{mg} \\
(0.91 \mathrm{~g})\end{array}$ & $\begin{array}{c}2752 \mathrm{mg} \\
(2.7 \mathrm{~g})\end{array}$ & $\begin{array}{c}9174 \mathrm{mg} \\
(9.75 \mathrm{~g})\end{array}$ & $\begin{array}{c}27,520 \mathrm{mg} \\
(27.5 \mathrm{~g})\end{array}$ & $41.2 \mathrm{~g}$ \\
\hline Cod raw mg $\$$ & $\begin{array}{c}17.64 \mathrm{mg} \\
(0.01 \mathrm{~g})\end{array}$ & $\begin{array}{c}58.82 \mathrm{mg} \\
(0.05 \mathrm{~g})\end{array}$ & $\begin{array}{c}176.4 \mathrm{mg} \\
(0.17 \mathrm{~g})\end{array}$ & $\begin{array}{c}582.2 \mathrm{mg} \\
(0.58 \mathrm{~g})\end{array}$ & $\begin{array}{c}1764 \mathrm{mg} \\
(1.7 \mathrm{~g})\end{array}$ & $\begin{array}{c}5822 \mathrm{mg} \\
(5.8 \mathrm{~g})\end{array}$ & $\begin{array}{c}17,640 \mathrm{mg} \\
(17.6 \mathrm{~g})\end{array}$ & $25.9 \mathrm{~g}$ \\
\hline Shrimp raw \& & $\begin{array}{c}22.05 \mathrm{mg} \\
(0.02 \mathrm{~g})\end{array}$ & $\begin{array}{c}73.52 \mathrm{mg} \\
(0.07 \mathrm{~g})\end{array}$ & $\begin{array}{c}220.5 \mathrm{mg} \\
(0.22 \mathrm{~g})\end{array}$ & $\begin{array}{c}735.2 \mathrm{mg} \\
(0.73 \mathrm{~g})\end{array}$ & $\begin{array}{c}2205 \mathrm{mg} \\
(2.2 \mathrm{~g})\end{array}$ & $\begin{array}{l}7352 \mathrm{mg} \\
(7.3 \mathrm{~g})\end{array}$ & $\begin{array}{l}22,050 \mathrm{mg} \\
(22 \mathrm{gr})\end{array}$ & $32.5 \mathrm{~g}$ \\
\hline Roasted peanut $^{\circ}$ & $\begin{array}{c}10.34 \mathrm{mg} \\
(0.01 \mathrm{~g})\end{array}$ & $\begin{array}{c}34.48 \mathrm{mg} \\
(0.03 \mathrm{~g})\end{array}$ & $\begin{array}{c}103.4 \mathrm{mg} \\
(0.1 \mathrm{~g})\end{array}$ & $\begin{array}{c}344.8 \mathrm{mg} \\
(0.34 \mathrm{~g})\end{array}$ & $\begin{array}{c}1.034 \mathrm{mg} \\
(1 \mathrm{~g})\end{array}$ & $\begin{array}{c}3.448 \mathrm{mg} \\
(3.4 \mathrm{~g})\end{array}$ & $\begin{array}{c}10.340 \mathrm{mg} \\
(10.3 \mathrm{~g})\end{array}$ & $15.1 \mathrm{~g}$ \\
\hline Hazelnut ${ }^{\mathbb{I}}$ & $\begin{array}{c}21.73 \mathrm{mg} \\
(0.02 \mathrm{~g})\end{array}$ & $\begin{array}{c}72.46 \mathrm{mg} \\
(0.07 \mathrm{~g})\end{array}$ & $\begin{array}{c}217.3 \mathrm{mg} \\
(0.21 \mathrm{~g})\end{array}$ & $\begin{array}{c}724.6 \mathrm{mg} \\
(0.72 \mathrm{~g})\end{array}$ & $\begin{array}{c}2.173 \mathrm{mg} \\
(2.1 \mathrm{~g})\end{array}$ & $\begin{array}{c}7.246 \mathrm{mg} \\
(7.2 \mathrm{~g})\end{array}$ & $\begin{array}{c}21.730 \mathrm{mg} \\
(21.7 \mathrm{~g})\end{array}$ & $32 \mathrm{~g}$ \\
\hline Walnut & $\begin{array}{c}28.57 \mathrm{mg} \\
(0.02 \mathrm{~g})\end{array}$ & $\begin{array}{c}95.23 \mathrm{mg} \\
(0.09 \mathrm{~g})\end{array}$ & $\begin{array}{c}285.7 \mathrm{mg} \\
(0.28 \mathrm{~g})\end{array}$ & $\begin{array}{c}952.3 \mathrm{mg} \\
(0.95 \mathrm{~g})\end{array}$ & $\begin{array}{c}2.857 \mathrm{mg} \\
(2.85 \mathrm{~g})\end{array}$ & $\begin{array}{c}9.523 \mathrm{mg} \\
(9.52 \mathrm{~g})\end{array}$ & $\begin{array}{c}28.570 \mathrm{mg} \\
(28.5 \mathrm{~g})\end{array}$ & $42.2 \mathrm{~g}$ \\
\hline
\end{tabular}

Protein content http://nut.entecra.it/646/tabelle_di_composizione_degli_alimenti.html (da INRAN 2009): ${ }^{*}$ protein content $3.3 \%$, ^ protein content $12.4 \%$, \# protein content $10.9 \%$, ${ }^{\$}$ protein content $17 \%$, \& protein content $13.6 \%$, ${ }^{\circ}$ protein content $29 \%$, II protein content $13,8 \%$, protein content $10.5 \%$.

An OFC with a very low starting dose (from 3-10 $\mu \mathrm{g}$ of protein) has been proposed for children with previous anaphylactic reactions [46]. The span of time between the doses usually varies from 15 to $30 \mathrm{~min}$, according to the type of protocol employed in the studies [8]. In those in which it is necessary to identify the threshold dose in order to start the oral immunotherapy, longer time intermissions are required to better define the tolerance or the allergy at each step [47]. The OFC is followed by a period of observation of about $2 \mathrm{~h}$ after the last dose of the food.

Labial challenges or lip challenges (putting a small amount of allergenic food on the inner and outer border of lip) is often used in the UK pediatric allergy center as an alternative or initial step of OFC. Variation in how lip challenges is performed and interpreted limits the reproducibility and the validity of the test and a recent study showed poor sensitivity [48].

\section{a) In non-IgE-Mediated Food Allergy}

The OFC in Food Protein Induced Enterocolitis Syndrome (PFIES) is always an open food challenge. A variety of protocols (FPIES) related to OFCs have been proposed. Although some protocols provide the entire dose in a single portion, a recent International Consensus suggests to administer the challenge food at a dose of 0.06 to $0.6 \mathrm{~g}$, usually $0.3 \mathrm{~g}$ of the food protein per kilogram of body weight, in three equal doses over $30 \mathrm{~min}$ [49]. It is generally recommended not to exceed a total of $3 \mathrm{~g}$ of protein or $10 \mathrm{~g}$ of total food (100 $\mathrm{mL}$ of liquid) for an initial feeding and observe the patient for 4 to $6 \mathrm{~h} \mathrm{[5].} \mathrm{Lower}$ starting doses, longer observation periods between doses, or both should be considered in patients with a history of severe reactions [50]. When a very low dose of food protein is administered and there is no reaction after 2 to $3 \mathrm{~h}$ of observation, some experts advocate that the patient could ingest a full age-appropriate serving of the food, followed by $4 \mathrm{~h}$ of observation [49].

\section{a) In Food-Induced Exercise-Induced Anaphylaxis}

The diagnosis of FDEIA is challenging, because even in typical case histories, a reaction cannot always be reproduced during the challenge with the suspected food in combination with exercise. A review of 234 reported cases of FDEIA found that food exercise + challenges successfully induced symptoms in approximately two-thirds of cases [51]. FDEIA seems to be a partial state of tolerance to food, whose pathophysiological mechanisms are complex and unclear [52]. Physical activity is the best known and most common reported co-factor responsible for insurgence of symptoms. The diversity in the reported level of exercise is wide, ranging from walking or playing to strenuous exercise. In these 
patients, aspirin and alcohol should also be considered as co-factors (or augmenting co-factors) equally with exercise able to lower the threshold and simultaneously increase the severity of the anaphylactic reaction. A standardized model for food challenges with the addition of different co-factors has not yet been developed. Several challenge procedures have been published, which have in common premedication with acetylsalicylic acid, relatively large amounts of the suspect food, and strenuous exercise. [53,54].

Christensen recently proposed a standardized challenge method for wheat-dependent exercise-induced anaphylaxis (WDEIA) using gluten, which could be applied to other foods. Starting with an initial titrated food challenge without any co-factor(s), this was followed by a food challenge in combination with exercise (or another co-factor). The starting dose was $1 / 10$ of the cumulated threshold based on the challenge without a co-factor, followed by $2 / 10,3 / 10$, and finally $4 / 10$. After each dosage, a treadmill test was performed for $15 \mathrm{~min}$ at a submaximal workload adapted to physical abilities of the individual patient. The treadmill test was performed to a maximum of four times or until objective signs occurred [55].

\section{Safety and Risk of an OFC}

Before performing an OFC, all risks associated with the test and the therapy needed in case of reaction shall be highlighted to parents, in order to receive the correct written informed consent $[56,57]$.

Systemic reaction rate (including lower respiratory and or laryngeal symptoms) differs depending on the inclusion criteria and the type of children admitted to the test [58]; the highest systemic reaction rate present in literature is $28 \%$ [59].

The severity of an adverse reaction cannot be always predicted. Several parameters have been used as indicators of development and severity of a potential adverse reaction during the OFC.

The most relevant factors to be considered as risk indicators are [4]:

(a) Possible underlying immunological mechanism (highest risk in IgE-mediated rather than non-IgE mediated, except the Food Protein Enterocolitis). IgE-mediated reactions include life-threatening anaphylaxis. Non IgE-mediated reactions induce above all gastrointestinal symptoms and could sometimes induce shock [60].

(b) The kind of allergen (especially peanuts, nuts, and seeds). In a report of 32 fatalities due to ingestion of allergenic food, peanuts and tree nuts accounted for more than $90 \%$ of the cases [61].

(c) The type of allergenic molecule (molecules with increasing resistance to hydrolysis, firing, or digestion are more dangerous). Ovoalbumin (OVA), the most abundant protein found in egg white, is quite sensitive to thermic denaturation, like other egg proteins, such as ovotransferrin and lysozyme [62] On the contrary, Ovomucoid (OVM) is relatively resistant to heat and is considered to be the dominant allergen in egg white [63].

(d) Age of the child (the risk increases with increasing age). It is well known that food allergy reactions generally worsen with increasing age [64] and food anaphylaxis death increases as children get older [65]. In a retrospective multicenter study of 544 OFCs, the median age of children that developed anaphylaxis was significantly higher than that of children with multi-organ reactions or mild reactions $(p=0.03)$ [19].

(e) Presence of asthma [3]. Food allergy-related fatal and near-fatal reactions in children have been reported to be caused by asthma. [66] In a report of 164 cases of food-induced anaphylaxis, a clinical history of asthma increased the risk of wheezing [odds ratio (OR) 2.2; 95\% confidence interval (CI) 1.1-4.5] and respiratory arrest (OR 6.9; 95\% CI 1.4-34.2). [67]

(f) Co-factors. The presence of some co-factors increases the risk of food allergy and affects the severity. Physical exercise, temperature, severe infections, pre-menstrual syndrome, emotional stress, the use of pharmaceutical drugs (FANS), and the ingestion of alcohol can enhance the development of some allergic reactions to a food [68]. 
(g) Criteria used to consider positive OFC (if one continues OFC, despite the onset of objective symptoms there is a higher possibility of severe allergic reactions). Wainstein enrolled 89 children with peanut allergy in a prospective study. The challenge protocol provided for the challenges had to be continued beyond initial mild reactions. Among the 21 children who developed anaphylaxis, in only 3 cases was the initial reaction anaphylaxis. The author suggests that "if the challenges had been stopped and treated when the initial milder reactions occurred, it is possible that only $3 / 21$ children would have developed anaphylaxis" [69]. Finally, since severe reactions might occur, the oral food challenge should be carried out by experienced physicians in a proper environment equipped for emergency, in order to correctly manage any possible allergic reaction. Intravenous access should be available before starting the OFC, especially if there is risk of anaphylaxis or other severe reactions, as in case of enterocolitis, or if there is any doubt about the possibility to place a cannula during an emergency [5]. It is also good practice to establish protocols to manage adverse reactions, including accurate posology for drugs.

\section{How to Interpret the Results}

There is currently no definitive agreement on the criteria for defining the positivity of a challenge in IgE-mediated food allergies. The decision to discontinue dosing is influenced by the patient's characteristics (clinical history), specific study protocols, purpose for which is conducted (diagnosis of food allergy or acquisition of tolerance), or to identify the threshold of responsiveness.

The OFC can result:

1. Positive, when clear objective signs of allergic reaction appear or repetitive (at least three times) or multiple subjective symptoms in several organ systems occur [6,8];

2. Negative, when no symptoms occur; or

3. Not conclusive (or conclusive only for partial tolerance) if the test is stopped before the total dose of food is ingested.

Interpretation of test results could be difficult in very young children, since some symptoms, both subjective and objective, may be hard to recognize. It is suggested to be aware of some signs that can prelude to more important symptoms such as behavioral changes (stop playing, appear quieter, stay in mother's arms), refusing food, putting hands into the mouth, and scratching ears or neck [70]. Tickling or itching in the throat, nausea, abdominal pain, or discomfort are the most common symptoms preluding more severe reactions in older children.

The OFC is considered diagnostic of FPIES (i.e., positive) if the major criterion (repetitive emesis in the 1- to 4-h period after ingestion of the suspect food and the absence of classic IgE-mediated allergic skin or respiratory symptoms) is met with $\geq 2$ minor criteria (lethargy, pallor, diarrhea $5-10 \mathrm{~h}$ after food ingestion, hypotension, hypothermia, increased neutrophil count of $>1500$ neutrophils above the baseline count [49].

\section{Management of Allergic Reactions}

In case of IgE-mediated allergic reaction, during the food challenge, the most important treatment purpose is to quickly stop the reaction, preventing the progression of its severity. Treatment with antihistamines, steroids, and infusion of $0.9 \%$ sodium chloride solution is usually applied in the presence of local or light-moderate systemic reactions, without cardiovascular and/or respiratory involvement [5]. In case of a systemic reaction development, IM in mid-outer thigh administration of adrenaline with a dose of $0.01 / \mathrm{kg}$ up to a maximum of $0.5 \mathrm{mg}$ is specified [5].

Rapid I.V. hydration $(20 \mathrm{~mL} / \mathrm{kg}$ normal saline bolus) is the first-line therapy for the severe acute reactions at large or during an FPIES positive OFC [49]. A single dose of intravenous methylprednisolone ( $1 \mathrm{mg} / \mathrm{kg}$; maximum, $60-80 \mathrm{mg}$ ) is often used for severe reactions, based on the presumed T cell-mediated intestinal inflammation, although no studies support this recommendation [71]. The use of intravenous 
ondansetron $(0.15-0.20 \mathrm{mg} / \mathrm{kg})$ can be helpful in stopping emesis during FPIES-related OFCs, as reported by two small case series [72,73].

\section{From OFC to Oral Immunotherapy: The Low Dose Challenge}

The concept of diet has changed a lot in the last ten years, and this had an impact in the way to execute OFCs. Practice Parameters in 2006 stated that after the diagnosis of food allergy has been confirmed correctly "complete avoidance of the implicated food(s) is the only proven form of prophylactic management currently available" [74].

Since then various studies have changed the dogma that strict dietary avoidance facilitates development of tolerance [75]. In fact, various studies have shown that repeated ingestion of the food allergens, starting with small doses and gradually growing, is able to induce desensitization, which consists of raising the threshold of reactivity to foods, whilst receiving food [76]. It has also been shown that about $70 \%$ of children with cow's milk or egg allergies are able to ingest muffin or waffle that contained milk or egg extensively heated, respectively [27,77].

Therefore, today, several guidelines suggest that, even if a strict dietary avoidance is the main food allergy therapy, the diet should be adapted to the tolerance of the individual child, being able to vary from a strict diet to the possibility of ingesting some proteins modified by cooking (such as extensively cooked milk and egg) [4,9]. Furthermore, since children seem to gradually develop tolerance to food, and it is a relief for families when their child can tolerate small amounts of these basic foods, even if larger doses may still cause symptoms, a low dose OFC was already proposed in 2006 [78]. Afterwards, several other authors have confirmed the effectiveness of this procedure [79] and, recently, Japanese Guidelines of Food Allergy (JGFA) have proposed that among the objectives of an OFC, there is also the identification of the amount of food that can be ingested without problems, in order to implement the "minimum diet of elimination". They suggest that a positive OFC does not always imply the need for complete elimination of a food allergen from the diet. Small amounts of food may be allowed to be taken, if tolerated. In particular, JGFA suggest strict dietary avoidance only in children who have experienced severe reactions at very low doses during an OFC. On the contrary, in those who have tolerated small doses of the food but have had allergic reactions at higher doses, JGFA suggest to continue to ingest a safe dose of $1-10 \%$ of the threshold dose in the following days [80].

All of this has had an effect also on the way the test is conducted. As a matter of fact, while in the past the aim of the OFC was to reach a maximum dose which should approximate that of an age-appropriate portion of the food [81], nowadays this objective is always valid for the first OFC that the patient undergoes, when the aim is to demonstrate the allergy. After the first OFC, in the following tests, when the objective is to demonstrate the possible development of the tolerance, it has been suggested to perform a low dose challenge, especially in children with a persistent allergy. The aim of a low dose challenge is to try to introduce at least low doses of the food and keep them in the diet, in order to facilitate the development of the tolerance (or, at least, to improve the quality of life by reducing the necessity of a strict diet) [78], or in order to test if infants have had a minimal clinical tolerance that allows starting oral immunotherapy $[82,83]$.

\section{Conclusions}

The diagnosis of food allergy is not simple because of its multiple clinical pictures and because diagnostic tests are not always sufficient to offer diagnostic certainty. However, the combination of history and diagnostic tests in some cases can provide sufficient diagnostic reliability to make the diagnosis of a food allergy without conducting an OFC. In all other cases, or if the certainty of diagnosis is sought, an OFC is required. Since severe reactions might occur, the oral food challenge should be carried out by experienced physicians in a proper environment, equipped for emergencies

Conflicts of Interest: Authors declare no conflict of interest. 


\section{Appendix A}

\section{Appendix A.1. Convincing Story (if it Satisfies All the Following Criteria)}

1. History of a recent allergic reaction to a food ( $<4$ months);

2. The clinical picture has to be evident in a few minutes or within $2 \mathrm{~h}$ from the ingestion of the food;

3. It has to be compatible with that of an IgE-mediated allergic reaction (vomit, urticaria, angioedema, rhino-conjunctivitis, asthma, etc.)

4. The reaction should appear after the isolated ingestion of the food;

5. The food has never been ingested before or only a very few times;

6. The food is a possible allergen at the age of the patient (e.g., the patient is younger than 1 year and the suspected food is milk or egg);

7. As a consequence to the reaction, the patient had to undergo therapy;

8. The rest of the patient's diet is consistent with the diagnostic suspicion (e.g., the same food has not been ingested at a later moment without evident reactions); and

9. With anamnesis. it is possible to exclude the possibility of another cause because of the clinical picture.

Appendix A.2. Suggestive Story (if it Satisfies All the Criteria)

History of a non-recent allergic reaction to a food ( $<12$ months);

1. The clinical picture has to be evident in a few minutes or within $2 \mathrm{~h}$ from the ingestion of the food;

2. It has to be compatible with that of an IgE-mediated allergic reaction (vomit, urticaria, angioedema, rhino conjunctivitis, asthma, etc.);

3. The reaction appears after the non-isolated ingestion of the food;

4. The food is a probable allergen according to the age range (e.g., the patient is younger than 1 year and the suspected food is milk or egg).

\section{References}

1. Nwaru, B.I.; Hickstein, L.; Panesar, S.S.; Roberts, G.; Muraro, A.; Sheikh, A.; EAACI Food Allergy and Anaphylaxis Guidelines Group. Prevalence of common food allergies in Europe: A systematic review and meta-analysis. Allergy 2014, 69, 992-1007. [CrossRef] [PubMed]

2. Eggesbø, M.; Halvorsen, R.; Tambs, K.; Botten, G. Prevalence of parentally perceived adverse reactions to foods in young children. Pediatr. Allergy Immunol. 1999, 10, 122-132. [CrossRef]

3. Sampson, H.A.; Aceves, S.; Bock, S.A.; James, J.; Jones, S.; Lang, D.; Nadeau, K.; Nowak-Wegrzyn, A.; Oppenheimer, J.; Perry, T.T.; et al. Joint Task Force on Practice Parameters. Food allergy: A practice parameter update-2014. J. Allergy Clin. Immunol. 2014, 134, 1016-1025. [PubMed]

4. Calvani, M.; Paravati, F.; Arasi, S.; Barni, S.; Bianchi, A.; Caimmi, D.; Comberiati, P.; Cuomo, B.; Mastrorilli, C.; Pelosi, U.; et al. Il test di provocazione orale per alimenti nella pratica clinica. RIAP 2018, 1, 1-51.

5. Nowak-Wegrzyn, A.; Assa'ad, A.H.; Bahna, S.L.; Bock, S.A.; Sicherer, S.H.; Teuber, S.S. Adverse Reactions to Food Committee of American Academy of Allergy, Asthma \& Immunology. Work Group report: Oral food challenge testing. J. Allergy Clin. Immunol. 2009, 123, S365-S383. [PubMed]

6. Grabenhenrich, L.B.; Reich, A.; Bellach, J.; Trendelenburg, V.; Sprikkelman, A.B.; Roberts, G.; Grimshaw, K.E.; Sigurdardottir, S.; Kowalski, M.L.; Papadopoulos, N.G.; et al. A new framework for the documentation and interpretation of oral food challenges in population-base and clinical research. Allergy 2017, 72, 453-461. [CrossRef] [PubMed]

7. Worm, M.; Reese, I.; Ballmer-Weber, B.; Beyer, K.; Bischoff, S.C.; Classen, M.; Fischer, P.J.; Fuchs, T.; Huttegger, I.; Jappe, U.; et al. Guidelines on the management of IgE mediated food allergies. Guidelines of the German Society for Allergology and Clinical Immunology DGAKI. Allergo J. Int. 2015, 24, 256-293. [CrossRef] 
8. Sampson, H.A.; Gerth van Wijk, R.; Bindslev-Jensen, C.; Sicherer, S.; Teuber, S.S.; Burks, A.W.; Dubois, A.E.; Beyer, K.; Eigenmann, P.A.; Spergel, J.M.; et al. Standardizing double-blind, placebo-controlled oral food challenges: American Academy of Allergy, Asthma \& Immunology-European Academy of Allergy and Clinical Immunology PRACTALL consensus report. J. Allergy Clin. Immunol. 2012, 130, 1260-1274.

9. Muraro, A.; Werfel, T.; Hoffmann-Sommergruber, K.; Roberts, G.; Beyer, K.; Bindslev-Jensen, C.; Cardona, V.; Dubois, A.; duToit, G.; Eigenmann, P.; et al. EAACI food allergy and anaphylaxis guidelines: Diagnosis and management of food allegy. Allergy 2014, 69, 1008-1025. [CrossRef]

10. Tanaka, S. An epidemiological survey on food-dependent exercise-induced anaphylaxis in kindergartners, schoolchildren and junior high school students. Asia Pac. J. Public Heath 1994, 7, 26-30. [CrossRef]

11. Christensen, M.J.; Eller, E.; Mortz, C.G.; Brokow, K.; Bindslev Jensen, C. Exercise Lowers Threshold and Increases Severity, but Wheat-Dependent, Exercise-Induced Anaphylaxis Can Be Elicited at Rest. J. Allergy Clin. Immunol. Pract. 2018, 6, 514-520. [CrossRef] [PubMed]

12. Sampson, H.A. Update on food allergy. J. Allergy Clin. Immunol. 2004, 113, 805-819. [CrossRef] [PubMed]

13. Sampson, H.A.; Ho, D.G. Relationship between food-specific IgE concentrations and the risk of positive food challenges in children and adolescents. J. Allergy Clin. Immunol. 1997, 100, 444-451. [CrossRef]

14. Calvani, M.; Arasi, S.; Bianchi, A.; Caimmi, D.; Cuomo, B.; Dondi, A.; Cosimo Indirli, G.; La Grutta, S.; Panetta, V.; Verga, M.C. Is it possible to make a diagnosis of raw, heated and baked egg allergy in children using cut-offs? A systematic review. Pediatr. Allergy Immunol. 2015, 26, 509-521. [CrossRef] [PubMed]

15. Bianchi, A.; Cuomo, B.; Arasi, S.; Caimmi, D.; Dondi, A.; Indirli, G.C.; La Grutta, S.; Panetta, V.; Verga, M.C.; Calvani, M. Revisione sistematica sul valore predittivo degli SPT nella diagnosi di allergia alle proteine del latte vaccino. Rivista di Immunologia e Allergologia Pediatrica 2016, 2, $27-41$.

16. Rancé, F.; Deschildre, A.; Villard-Truc, F.; Gomez, S.A.; Paty, E.; Santos, C.; Couderc, L.; Fauquert, J.L.; De Blic, J.; Bidat, E.; et al. SFAIC and SP2A Workgroup on OFC in Children. Oral food challenge in children: An expert review. Eur. Ann. Allergy Clin. Immunol. 2009, 41, 35-49. [PubMed]

17. Hill, D.J.; Heine, R.G.; Hosking, C.S. The diagnostic value of skin prick testing in children with food allergy. Pediatr. Allergy Immunol. 2004, 15, 435-441. [CrossRef] [PubMed]

18. Leonard, S.A.; Sampson, H.A.; Sicherer, S.H.; Noone, S.; Moshier, E.R.; Godbold, J.; Nowak-Wegrzyn, A. Dietary baked egg accelerates resolution of egg allergy in children. J. Allergy Clin. Immunol. 2012, 130, 473-480. [CrossRef] [PubMed]

19. Calvani, M.; Berti, I.; Fiocchi, A.; Galli, E.; Giorgio, V.; Martelli, A.; Miceli Sopo, S.; Panetta, V. Oral food challenge: Safety, adherence to guidelines and predictive value of skin prick testing. Pediatr. Allergy Immunol. 2012, 23, 755-761. [CrossRef]

20. Cuomo, B.; Indirli, G.C.; Bianchi, A.; Caimmi, D.; Dondi, A.; La Grutta, S.; Panetta, V.; Verga, M.C.; Calvani, M. Specific IgE and skin prick tests to diagnose allergy to fresh and baked cow's milk according to age: A systematic review. Ital. J. Pediatr. 2017, 43, 1-10. [CrossRef]

21. Whiting, P.F.; Rutjes, A.W.; Westwood, M.E.; Mallett, S.; Deeks, J.J.; Reitsma, J.B.; Leeflang, M.M.; Sterne, J.A.; Boussuyt, P.M. QUADAS-2: A revised tool for the quality assessment of diagnostic accuracy studies. Ann. Intern. Med. 2011, 155, 529-536. [CrossRef] [PubMed]

22. Garcia-Ara, C.; Boyano-Martinez, T.; Diaz-Pena, J.M.; Martin-Muñoz, F.; Reche-Frutos, M.; Martin-Esteban, M. Specific IgE levels in the diagnosis of immediate hypersensitivity to cow's milk protein in the infant. J. Allergy Clin. Immunol. 2001, 107, 185-190. [CrossRef] [PubMed]

23. Saarinen, K.M.; Suomalainen, H.; Savilahti, E. Diagnostic value of skin-prick and patch tests and serum eosinophil cationic protein and cow's milk-specific IgE in infants with cow's milk allergy. Clin. Exp. Allergy 2001, 31, 423-429. [CrossRef] [PubMed]

24. Stiefel, G.; Anagnostou, K.; Boyle, R.J.; Brathwaite, N.; Ewan, P.; Fox, A.T.; Huber, P.; Luyt, D.; Till, S.J.; Venter, C.; et al. BSACI guideline for the diagnosis and management of peanut and three nut allergy. Clin. Exp. Allergy 2017, 47, 719-739. [CrossRef] [PubMed]

25. Sporik, R.; Hill, D.J.; Hosking, C.S. Specificity of allergen skin testing in predicting positive open food challenges to milk, egg and peanut in children. Clin. Exp. Allergy 2000, 30, 1540-1546. [CrossRef] [PubMed]

26. Onesimo, R.; Monaco, S.; Greco, M.; Caffarelli, C.; Calvani, M.; Tripodi, S.; Sopo, S. Predictive value of MP4 (Milk Prick Four), a panel of skin prick test for the diagnosis of pediatric immediate cow's milk allergy. Eur. Ann. Allergy Clin. Immunol. 2013, 45, 201-208. [PubMed] 
27. Nowak-Wegrzyn, A.; Bloom, K.A.; Sicherer, S.H.; Shreffler, W.G.; Noone, S.; Wanich, N.; Sampson, H.A. Tolerance to extensively heated milk in children with cow's milk allergy. J. Allergy Clin. Immunol. 2008, 122, 342-347. [CrossRef]

28. Keskin, O.; Tuncer, A.; Adalioglu, G.; Sekerel, B.E.; Sackesen, C.; Kalayci, O. Evaluation of the utility of atopy patch testing, skin prick testing, and total and specific IgE assays in the diagnosis of cow's milk allergy. Ann. Allergy Asthma Immunol. 2005, 94, 553-560. [CrossRef]

29. Peters, R.L.; Allen, K.J.; Dharmage, S.C.; Tang, M.L.; Koplin, J.J.; Ponsonby, A.L.; Lowe, A.J.; Hill, D.; Gurrin, L.C.; Health Nuts Study. Skin prick test responses and allergen specific IgE levels as predictors of peanut, egg, and sesame allergy in infants. J. Allergy Clin. Immunol. 2013, 132, 874-880. [CrossRef]

30. Vazquez-Ortiz, M.; Pascal, M.; Jimenez-Feijoo, R.; Lozano, J.; Giner, M.T.; Alsina, L.; Martin-Mateos, M.A.; Plaza, A.M. Ovalbumin-specific IgE/IgG4 ratio might improve the prediction of cooked and uncooked egg tolerance development in egg allergic children. Clin. Exp. Allergy 2014, 44, 579-588. [CrossRef]

31. Mehl, A.; Rolinck-Werninghaus, C.; Staden, U.; Verstege, A.; Wahn, U.; Beyer, K.; Niggemann, B. The atopy patch test in the diagnostic workup of suspected food-related symptoms in children. J. Allergy Clin. Immunol. 2006, 118, 923-929. [CrossRef] [PubMed]

32. Sampson, H.A. Utility of food-specific IgE concentrations in predicting symptomatic food allergy. J. Allergy Clin. Immunol. 2001, 107, 891-896. [CrossRef]

33. Ando, H.; Moverare, R.; Kondo, Y.; Tsuge, I.; Tanaka, A.; Borres, M.P.; Urisu, A. Utility of ovomucoid-specific IgE concentrations in predicting symptomatic egg allergy. J. Allergy Clin. Immunol. 2008, 122, 583-588. [CrossRef] [PubMed]

34. Valenta, R.; Lidholm, J.; Niederberger, V.; Hayek, B.; Kraft, D.; Grönlund, H. The recombinant allergen-based concept of component-resolved diagnostics and immunotherapy (CRD and CRIT). Clin. Exp. Allergy 1999, 29, 896-904. [CrossRef]

35. Luenga, O.; Cardona, V. Component resolved diagnosis: When should be used? Clin. Transl. Allergy 2014, 4, 28. [CrossRef] [PubMed]

36. Tuano, K.S.; Davis, C.M. Utility of Component-Resolved Diagnostic in food allergy. Curr. Allergy Asthma Rep. 2015, 15, 32. [CrossRef] [PubMed]

37. Patelis, A.; Borres, M.P.; Kober, A.; Berthold, M. Multiplex component-based allergen microarray in recent clinical studies. Clin. Exp. Allergy 2016, 46, 1022-1032. [CrossRef] [PubMed]

38. Matricardi, P.M.; Kleine-Tebbe, J.; Hoffmann, H.J.; Valenta, R.; Hilger, C.; Hofmaier, S.; Aalberse, R.C.; Agache, I.; Asero, R.; Ballmer Weber, B.; et al. EAACI molecular allergology User's guide. Pediatr. Allergy Immunol. 2016, 27, 1-250. [CrossRef]

39. Ruinemans-Koerts, J.; Schmidtt-Hieljes, Y.; Jansen, A.; Savelkoul, H.F.J.; Plaisier, A.; van Setten, P. The basophil activation test reduces the need for a challenge test in children suspected of IgE mediated cow's milk allergy. Clin. Exp. Allergy 2019, 49, 350-356. [CrossRef]

40. Sato, S.; Tachimoto, H.; Shukuya, A.; Kurosaka, N.; Yanagida, N.; Utsunomiya, T.; Iguchi, M.; Komata, T.; Imai, T.; Tomikawa, M.; et al. Basophil activation marker CD203c is useful in the diagnosis of hen's egg and cow's milk allergies in children. Int. Arch. Allergy Immunol. 2010, 152, 54-61. [CrossRef]

41. Santos, A.F.; Douiri, A.; Becares, N.; Wu, S.Y.; Stephens, A.; Radulovic, S.; Chan, S.M.H.; Fox, A.T.; Du Toit, G.; Turcanu, V.; et al. Basophil activation test discriminates between allergy. J. Allergy Clin. Immunol. 2014, 134, 645-652. [CrossRef]

42. Sterne, K. Essential Medical Statistics, 2nd ed.; Blackwell Science Ltd.: Melbourne, Australia, 2003.

43. Ito, K. Diagnosis of food allergies: The impact of oral food challenge testing. Asia Pac. Allergy 2013, 3, 59-69. [CrossRef]

44. Stiefel, G.; Roberts, G. How to use serum-specific IgE measurements in diagnosing and monitoring food allergy. Arch. Dis. Child. Educ. Pract. Ed. 2012, 97, 29-36. [CrossRef] [PubMed]

45. Kowalski, M.L.; Ansotegui, I.; Aberer, W.; Al-Ahmad, M.; Akdis, M.; Ballmer Weber, B.K.; Beyer, K.; Bianca, M.; Brown, S.; Bunnag, C.; et al. Risk and safety requirements for diagnostic and therapeutic procedures in allergology: World Allergy Organization Statement. World Allergy Organ. J. 2016, 9, 33. [CrossRef] [PubMed]

46. Cochrane, S.A.; Salt, L.J.; Wantling, E.; Rogers, A.; Coutts, J.; Ballmer-Weber, B.K.; Fritsche, P.; Fernández-Rivas, M.; Reig, I.; Knulst, A.; et al. Development of a standardized low-dose double-blind placebo-controlled challenge vehicle for the EuroPrevall project. Allergy 2012, 67, 107-113. [CrossRef] 
47. Blumchen, K.; Beder, A.; Beschorner, J.; Ahrens, F.; Gruebl, A.; Hamelmann, E.; Hansen, G.; Heinzmann, A.; Nemat, K.; Niggemann, B.; et al. Modified oral food challenge used with sensitization biomarkers provides more real- life clinical thresholds for peanut allergy. J. Allergy Clin. Immunol. 2014, 134, 390-398. [CrossRef] [PubMed]

48. Vazquez-Ortiz, M.; Ludman, S.; Aston, A.; Noimark, L.; Turner, P.J. Lip Dose Challenges in Food Allergy: Current Practice and Diagnostic Utility in the United Kingdom. J. Allery Clin. Immunol. Practice 2019, in press. [CrossRef] [PubMed]

49. Nowak-Wegrzyn, A.; Chehade, M.; Groetch, M.E.; Spergel, J.M.; Wood, R.A.; Allen, K.; Atkins, D.; Sami Bahna, S.; Barad, A.V.; Berin, C.; et al. International consensus guidelines for the diagnosis and management of food protein-induced enterocolitis syndrome: Executive summary-workgroup report of the adverse reactions to foods committee, American Academy of Allergy, Asthma \& Immunology. J. Allergy Clin. Immunol. 2017, 139, 1111-1126. [PubMed]

50. Sicherer, S.H. Food protein-induced enterocolitis syndrome: Case presentations and management lessons. J. Allergy Clin. Immunol. 2005, 115, 149-156. [CrossRef]

51. Hanakawa, Y.; Tohyama, M.; Shirakata, Y.; Murakami, S.; Hashimoto, K. Fooddependent exercise-induced anaphylaxis: A case related to the amount of food allergen ingested. Br. J. Dermatol. 1998, 138, 898-900. [CrossRef]

52. Barg, W.; Medrala, W.; Wolanczyk-Medrala, A. Exercise-induced anaphylaxis: An update on diagnosis and treatment. Curr. Allergy Asthma. Rep. 2011, 11, 45-51. [CrossRef] [PubMed]

53. Brockow, K.; Kneissl, D.; Valentini, L.; Zelger, O.; Grosber, M.; Kugler, C.; Werich, M.; Darsow, U.; Matsuo, H.; Morita, E.; et al. Using a gluten oral food challenge protocol to improve diagnosis of wheatdependent exercise-induced anaphylaxis. J. Allergy Clin. Immunol. 2015, 135, 977-984. [CrossRef] [PubMed]

54. Asaumi, T.; Yanagida, N.; Sato, S.; Shukuya, A.; Nishino, M.; Ebisawa, M. Provocation tests for the diagnosis of food-dependent exercise-induced anaphylaxis. Pediatr. Allergy Immunol. 2016, 27, 44-49. [CrossRef] [PubMed]

55. Christensen, M.J.; Eller, E.; Kjaer, H.F.; Broesby Olsen Mortz, C.G.; Bindslev Jensen, C. Exercise-induced anaphylaxis: Causes, consequences and management recommendations. Expert Rev. Clin. Immunol. 2019, 15, 265-273. [CrossRef] [PubMed]

56. Ebisawa, M.; Ito, K.; Fujisawa, T. Japanese guidelines for food allergy 2017. Allergol Int. 2017, 66, $248-264$. [CrossRef] [PubMed]

57. Ricci, G.; Berti, I.; Macr, F.; Andrea Minarini, A.; Pelosi, U. Bernardini R e Direttivo SIAIP 2014 Perché e come esprimere il Consenso Informato in Allergologia Pediatrica. Riv. Immunol. Allergol. Pediatr. 2015, 1, $2-12$.

58. Cianferoni, A.; Khullar, K.; Saltzman, R.; Fiedler, J.; Garrett, J.P.; Naimi, D.R.; Spergel, J.M. Oral food challenge to wheat: A near-fatal anaphylaxis and review of 93 food challenges in children. World Allergy Organ. J. 2013, 6, 14. [CrossRef] [PubMed]

59. Perry, T.; Matsui, E.C.; Conover-Walker, M.K.; Wood, R.A. Risk of oral challenges. J. Allergy Clin. Immunol. 2004, 114, 1164-1168. [CrossRef]

60. Saarinen, K.M.; Pelkonen, A.S.; Makela, M.J.; Savilahti, E. Clinical course and prognosis of cow's milk allergy are dependent on milk-specific IgE status. J. Allergy Clin. Immunol. 2005, 116, 869-875. [CrossRef]

61. Bock, S.A.; Munoz-Furlong, A.; Sampson, H.A. Fatalities due to anaphylactic reactions to food. J. Allergy Clin. Immunol. 2001, 107, 191-193. [CrossRef]

62. Joo, K.; Kato, Y. Assessment of allergenic activity of a heat-coagulated ovalbumin after in vivo digestion. Biosci. Biotechnol. Biochem. 2006, 70, 591-597. [CrossRef] [PubMed]

63. Cooke, S.K.; Sampson, H.A. Allergenic properties of ovomucoid in man. J. Immunol. 1997, 159, $2026-2032$. [PubMed]

64. Jarvinen, K.M. Food-induced anaphylaxis. Curr. Opin. Allergy Clin. Immmunol. 2011, 11, 255-261. [CrossRef] [PubMed]

65. Liew, W.K.; Williamson, E.; Tang, M.L.K. Anaphylaxis fatalities and admissions in Australia. J. Allergy Clin. Immunol. 2009, 123, 434-442. [CrossRef] [PubMed]

66. Pumphrey, R.S.H.; Roberts, I.S.D. Postmortem findings after fatal anaphylactic reactions. J. Clin. Pathol. 2000, 53, 273-276. [CrossRef] [PubMed] 
67. Calvani, M.; Cardinale, F.; Martelli, A.; Muraro, A.; Pucci, N.; Savino, S.; Zappalà, D.; Panetta, V.; Italian Society of Pediatric Allergy and Immunology Anaphylaxis' Study Group. Risk factor for severe pediatric anaphylaxis in Italy. Pediatr. Allergy Immunol. 2011, 22, 813-819. [CrossRef] [PubMed]

68. Turner, P.J.; Baumert, J.L.; Beyer, K.; Boule, R.J.; Chan, C.H.; Clark, A.T.; Crevel, R.W.R.; DunnGalvin, A.; Fernandez-Rivas, M.; Gowland, M.H.; et al. Can we identify patients at risk of life-threatening allergic reactions to food? Allergy 2016, 71, 1241-1255. [CrossRef] [PubMed]

69. Wainstein, B.K.; Studdert, J.; Ziegler, M.; Ziegler, J.B. Prediction of anaphylaxis during peanut food challenge: Usefulness of the peanut skin prick test (SPT) and specific IgE level. Pediatr. Allergy Immunol. 2010, 21, 603-611. [CrossRef]

70. Bird, J.A.; Groetch, M.; Allen, K.J.; Bock, S.A.; Leonard, S.; Nowak-Wegrzyn, A.H.; Sicherer, S.; Clark, A.; Fleischer, D.M.; Venter, C.; et al. Conducting an Oral Food Challenge to peanut in infant. J. Allergy Clin. Immunol. Pract 2017, 5, 301-311. [CrossRef]

71. Sicherer, S.H. Food protein-induced entercolitis syndrome: Clinical perspectives. J. Pediatr. Gastroenterol. Nutr. 2000, 30, 45-49. [CrossRef]

72. Holbrook, T.; Keet, C.A.; Frischmeyer-Guerrerio, P.A.; Wood, R.A. Use of ondansetron for food protein-induced enterocolitis syndrome. J. Allergy Clin. Immunol. 2013, 132, 1219-1220. [CrossRef] [PubMed]

73. Miceli Sopo, S.; Greco, M.; Monaco, S. Ondansetron for food protein-induced enterocolitis syndrome. Int. Arch. Allergy Immunol. 2014, 164, 137-139. [CrossRef] [PubMed]

74. Chapman, J.A.; Bernstein, I.L.; Lee, R.E.; Oppenheimer, J.; Nicklas, R.A.; Portnoy, J.M.; Sicherer, S.H.; Schuller, D.A.; Spector, S.L.; Khan, D.; et al. Food Allergy: A practice parameter. Annals Allergy Asthma Immunol. 2006, 96, 1-50. [CrossRef]

75. Sicherer, S.H.; Bock, S.A. An expanding evidence base provised food for thought to avoid indigestion in managing difficult dilemmas in food allergy. J. Allergy Clin. Immunol. 2006, 117, 1419-1422. [CrossRef] [PubMed]

76. Pajno, G.B.; Fernandez-Rivas, M.; Arasi, S.; Roberts, G.; Akdis, C.A.; Alvaro-Lozano, A.; Beyer, K.; Bindslev-Jensen, C.; Burks, W.; Ebisawa, M.; et al. EAACI Guidelines on allergen immunotherapy: $\operatorname{IgE}$ mediated food allergy. Allergy 2018, 73, 799-815. [CrossRef] [PubMed]

77. Lemon-Mulè, H.; Sampson, H.A.; Sicherer, S.H.; Shreffler, W.G.; Noone, S.; Nowak-Wegrzyn, A. Immunologic changes in children with egg allergy ingesting extensively heated egg. J. Allergy Clin. Immunol. 2008, 122, 977-983. [CrossRef] [PubMed]

78. Devenney, I.; Norrman, G.; Oldaeus, G.; Stromberg, L.; Falth-Magnusson, K. A new model for low-dose food challenge in children with allergy to milk and egg. Acta Paediatr. 2006, 95, 1133-1139. [CrossRef]

79. Okada, Y.; Yanagida, N.; Sato, S.; Ebisawa, M. Better management of wheat allergy using a very low-dose food challenge: A retrospective study. Allergol. Int. 2016, 65, 82-87. [CrossRef]

80. Urisu, A.; Ebisawa, M.; Ito, K.; Aihara, Y.; Ito, S.; Mayumi, M.; Kohno, Y.; Kondo, N. Japanese Society of allergology. Japanese guideline for food allergy. Allergol. Int. 2011, 60, 221-236. [CrossRef]

81. Du Toit, G.; Santos, A.; Roberts, G.; Fox, A.T.; Smith, P.; Lack, G. The diagnosis of IgE-mediated food allergy in childhood. Pediatr. Allergy Immunol. 2009, 20, 309-319. [CrossRef]

82. Berti, I.; Badina, L.; Cozzi, G.; Giangreco, M.; Bibalo, C.; Ronfani, L.; Barbi, E.; Ventura, S.; Longo, S. Early oral immunotherapy in infants with cow's milk protein allergy. Pediatr. Allergy Immunol. 2019, 30, 572-574. [CrossRef] [PubMed]

83. Yanagida, N.; Okada, Y.; Sato, S.; Ebisawa, M. New approach for food allergy management using low-dose oral food challenges and low-dose oral immunotherapies. Allergol. Int. 2016, 65, 135-140. [CrossRef] [PubMed]

(C) 2019 by the authors. Licensee MDPI, Basel, Switzerland. This article is an open access article distributed under the terms and conditions of the Creative Commons Attribution (CC BY) license (http://creativecommons.org/licenses/by/4.0/). 